\title{
SUSTAINABLE RIVER WATER QUALITY MANAGEMENT IN MALAYSIA
}

\author{
Abdullah A. Mamun and Zaki Zainudin \\ Bioenvironmental Engineering Research Center (BERC), Department of Biotechnology \\ Engineering, Faculty of Engineering, International Islamic University Malaysia, \\ Jalan Gombak, 53100 Kuala Lumpur, Malaysia. \\ mamun@iium.edu.my
}

ABSTRACT: Ecological status of Malaysia is not as bad as many other developing nations in the world. However, despite the enforcement of the Environmental Quality Act (EQA) in 1974, the water quality of Malaysian inland water (especially rivers) is following a deteriorating trend. The rivers are mainly polluted due to the point and nonpoint pollution sources. Point sources are monitored and controlled by the Department of Environment (DOE), whereas a significant amount of pollutants is contributed by both untreated sullage and storm runoff. Nevertheless, it is not too late to take some bold steps for the effective control of non-point source pollution and untreated sullage discharge, which play significant roles on the status of the rivers. This paper reviews the existing procedures and guidelines related to protection of the river water quality in Malaysia. There is a good possibility that the sewage and effluent discharge limits in the Environmental Quality Act (EQA) may pose hindrance against achieving good quality water in the rivers as required by the National Water Quality Standards (NWQS). For instance, Ammoniacal Nitrogen $\left(\mathrm{NH}_{3}-\mathrm{N}\right)$ is identified as one of the main pollutants to render many of the rivers polluted but it was not considered in the EQA as a monitoring parameter until the new regulations published in 2009. Surprisingly, the new regulation for sewage and industrial effluent limits set allowable $\mathrm{NH}_{3}-\mathrm{N}$ concentration quite high (5 $\mathrm{mg} / \mathrm{L}$ ), which may result in low Water Quality Index (WQI) values for the river water. The water environment is a dynamic system. Periodical review of the monitoring requirements, detecting emerging pollutants in sewage, effluent and runoff, and proper revision of water quality standards are essential for the management of sustainable water resources, in the country.

ABSTRAK: Satus ekologi Malaysia tidak seburuk kebanyakan negara membangun lain di dunia. Walaupun Akta Kualiti Alam Sekitar (EQA) dikuatkuasakan pada tahun 1974, kualiti air di pedalaman Malaysia (terutama sungai) semakin merosot. Kebanyakan sungai tercemar akibat pencemaran di punca sumber air dan pencemaran di bukan punca sumber air. Punca sumber air dipantau dan dikawal oleh Jabatan Alam Sekitar (JAS), tetapi sejumlah besar pencemaran adalah sisa yang tidak dirawat dan air larian ribut. Walau bagaimanapun, ia tidak terlambat untuk mengambil beberapa langkah berani untuk mengawal pencemaran di punca sumber air dan sisa tidak dirawat kerana langkah ini memainkan peranan penting bagi kebersihan sungai. Kertas kerja ini mengkaji prosedur dan garis panduan sedia ada berkaitan perlindungan kualiti air sungai di Malaysia. Ada kemungkinan bahawa had kumbahan dan pelepasan efluen dalam Akta Kualiti Alam Sekitar (EQA) boleh menimbulkan halangan terhadap mencapai kualiti air yang baik di dalam sungai seperti yang dikehendaki oleh Piawaian Kualiti Kebangsaan Air (NWQS). Sebagai contoh, Ammoniakal Nitrogen $\left(\mathrm{NH}_{3}-\mathrm{N}\right)$ dikenal pasti sebagai salah satu bahan pencemar utama yang menyebabkan banyak sungai tercemar tetapi ia tidak dianggap sebagai parameter pemantauan dalam EQA hingga peraturan baru diterbitkan pada tahun 2009. Yang menghairankan, peraturan baru menetapkan had 
efluen perindustrian dan kumbahan dibenarkan pada kepekatan $\mathrm{NH}_{3}-\mathrm{N}$ yang agak tinggi (5 mg / 1), dan ini mungkin menyebabkan nilai Indeks Kualiti Air (WQI) sungai rendah. Persekitaran air adalah sistem dinamik. Menjalankan semakan berkala mengenai syarat pemantauan, mengesan bahan pencemaran di dalam kumbahan, efluen dan aliran, dan semakan piawaian kualiti air yang wajar adalah perlu bagi pengurusan sumber air lestari di negara ini.

KEYWORDS: Environmental Quality Act (EQA); point source (PS); non-point source (NPS); sustainable uses; Water Quality Index (WQI)

\section{INTRODUCTION}

Good quality water is essential for all living beings. Even modern technologies could not change our dependency on water. We are more concern about this natural resource when it becomes too little, too much or too dirty. Until recently, the quantity of water was not an issue in the country, except in the dry regions of the Peninsula. Sabah and Sarawak did not face any serious shortage of raw water yet. Majority of the potable water is tapped from the rivers, which are fed by the rain. On average the Peninsular Malaysia receives 324 billion $\mathrm{m}^{3}$ of rainwater annually, where as the current demand is about 11 billion $\mathrm{m}^{3}$ only [1]. The demand in the year 2050 could be about 18 billion $\mathrm{m}^{3}$. As such, it is understood that the availability of raw water in the country, generally, is not an issue. The problem is due to the fact that rainfall is not uniformly distributed over the year temporally and spatially; baseflow is reduced due to urbanisation, supply is less than the demand in the city centres, distribution network is not adequate to transfer water from the low demand to the high demand areas, water get polluted and rendered less suitable for the intakes when passing through the urban centres.

Variation of annual rainfall is not that significant in Malaysia except during the ElNino spells. The annual rainfall at one of the well maintained gauging station at DID Ampang branch is shown in Fig. 1. Despite ignoring the rainfall during the missing days, the recorded data showed a slightly increasing trend of annual rainfall. Thus, water scarcity is not a common phenomenon in Malaysia. The recent shortages are due to nonuniformity of rainfall and improper distribution and management of the water resources. However, availability of good quality raw water is reducing. This is reflected in the number of polluted and slightly polluted rivers are increasing, as shown in Fig. 2. Shortage of water is mainly faced in the city centres where the water demand is high. Besides quantity, quality of water resources also concerns the relevant authorities. Quality of the surface water is degraded by point and non-point sources pollutants. Legislations are available in the form of Environmental Quality Act (EQA) 1974, which deals mainly with point source pollutants from the domestic and industrial sources [2]. Other regulatory Acts are available at State and Federal levels to protect the rivers.

Besides the point sources (sewage, sullage, industrial effluent, etc.), pollutants from the non-point sources (urban and rural runoff) are also responsible to make river water unsuitable for our uses. Management of the pollutants from the point and non-point sources are equally important for sustainable management of water resources. This statement is apparently true as it is observed that despite the implementation of the EQA for more than two decades (which mainly controls point sources) the trend of river water quality is not improving until 2000. It is the year 2001 when significant improvement in the river water quality status was observed which might be linked to the endorsement of the urban stormwater management manual for Malaysia (Manual Saliran Mesra Alam, MSMA) by the cabinet in 2000 [3]. 


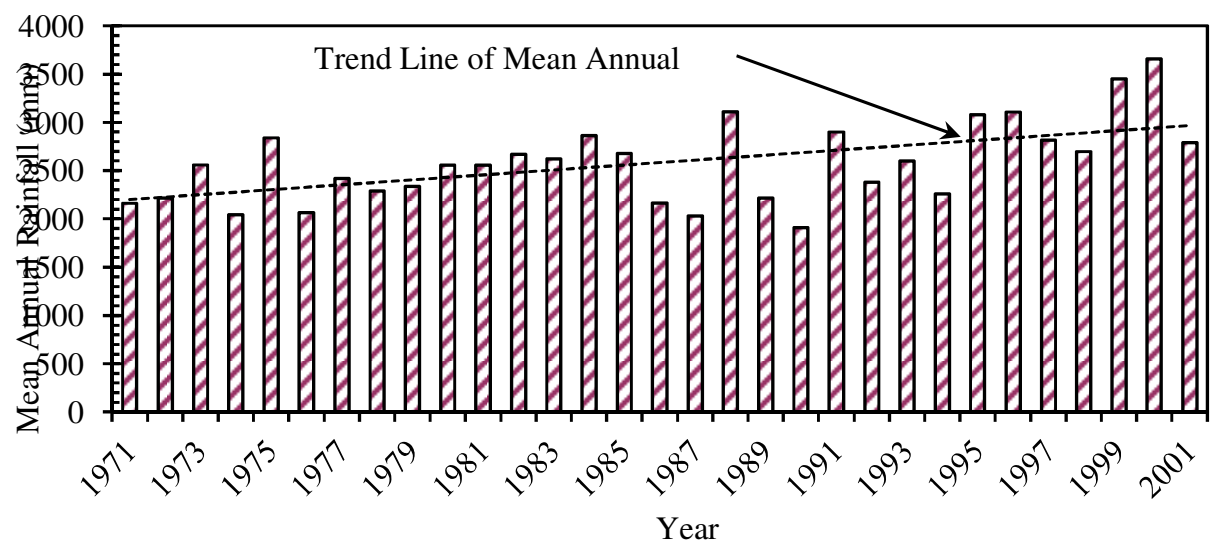

Fig. 1: Variation of mean annual rainfall at Ampang (Stn. No. 3117070).

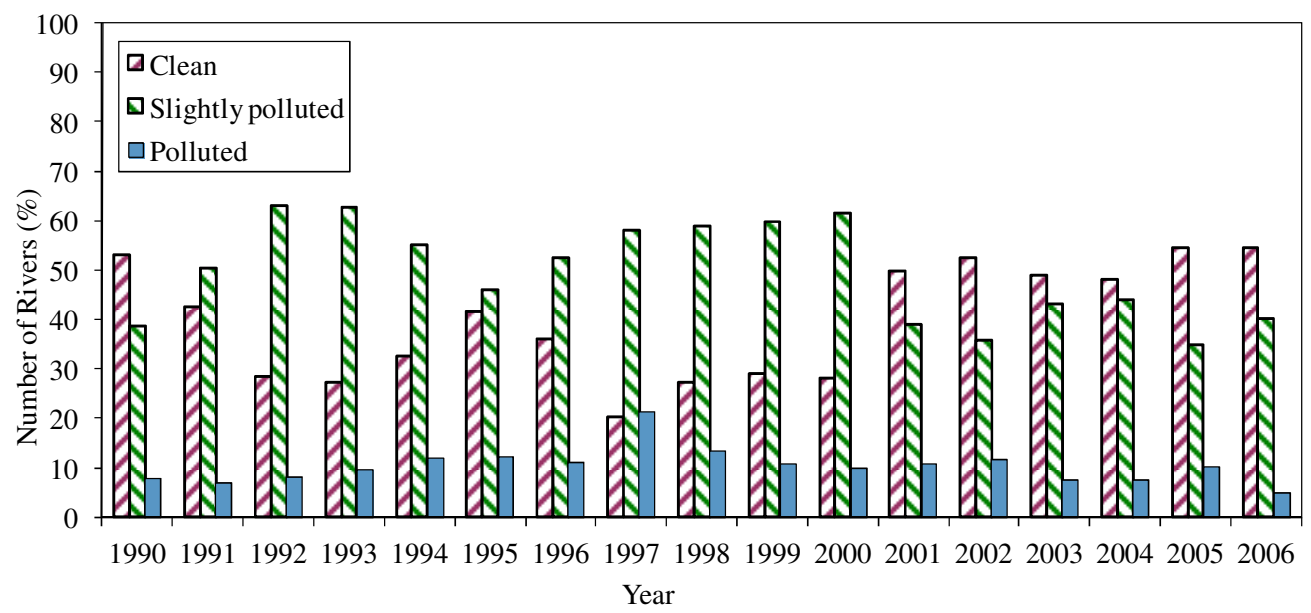

Fig. 2: River water quality trend in Malaysia (Source: DOE Malaysia).

The quality of raw water is crucial for the uninterrupted supply of potable water [4]. There are about 468 water treatment plants (WTPs) in the country. Many of WTPs use conventional treatment technology. Therefore, the WTPs have their own limitations in treating polluted water for potable use. Such limitations can affect the availability of water supply in the country due to the issue of raw water quality despite availability of adequate amount of polluted water in the rivers. Elevated level of ammoniacal nitrogen $\left(\mathrm{NH}_{3}-\mathrm{N}\right)$ had resulted in the temporary closing of the Cheras WTP thrice in 1997 [4]. More than 30\% of the raw water samples taken in the year 2000 by the Ministry of Health had total bacteria counts above 5,000 CFU/100 ml, the Malaysian Water Association (MWA) and World Health Organisation (WHO) standards for raw water. The consequences of polluted raw water include the risk of outbreaking waterborne diseases. The microbial and heavy metal contamination in raw water also can affect the food chain and result in serious health impacts.

According to the present practice, the overall river quality is determined based on six (6) parameters, among which $\mathrm{NH}_{3}-\mathrm{N}$ was not listed either in Standard A or Standard B of the EQA until the year 2009. It was reported that $43 \%$ of the rivers are polluted with ammoniacal nitrogen [5]. Suspended solid (SS) is another pollutant, which is contributed from the non-point sources during storm events but not monitored in the DOE approved 
programs. Interruption and temporary shut down of Cheras, Bukit Jelutong at Shah Alam, Sungai Buaya and a few other water treatment plants (WTPs) in the country indicates that quality of raw water is also important for sustainable supply. Sustainable water use supports the ability of human society to endure and flourish into the indefinite future without undermining the integrity of the hydrological cycle or the ecological systems that depend on it [6]. As such, it is important to consider the quality of water and wastewater for sustainable management of water resources in this country.

\section{SOURCES OF RIVER WATER POLLUTION}

Over the past few decades, the situation of good quality water in the country has changed from one of relative abundance to one of relative scarcity [6]. Rivers are polluted from point and non-point sources. Domestic and industrial wastewater are the main point sources responsible for degraded river water. It is expected that after treatment, the treated wastewater would achieve either Standard A or B. Not much data is available on the longterm performance of the existing sewage or industrial wastewater treatment plants. Without any detailed data, it would be impossible to evaluate the contribution of the wastewater on water pollution.

In order to evaluate the contribution of pollutants from the non-point sources, a comprehensive study done in the USA can be referred to [7]. Event mean concentration (EMC), which represents the flow-weighted pollutant concentration for any storm event, of a few selected pollutants are given in Table 1.

Table 1: Typical pollutant concentrations in storm runoff [7] and DOE, 2009.

\begin{tabular}{lcccccc}
\hline \multirow{2}{*}{ Source } & \multicolumn{7}{c}{ Event Mean Concentration, EMC (mg/l) } \\
\cline { 2 - 7 } & BOD & COD & TSS & Cu & Zn & Cd \\
\hline Residential runoff (NPS) & 10.0 & 80.0 & 139.0 & 0.05 & 0.17 & 0.002 \\
Industrial runoff (NPS) & 9.5 & 60.0 & 87.0 & 0.05 & 0.32 & 0.002 \\
Agricultural runoff (NPS) & 8.5 & 55.0 & 52.0 & - & - & - \\
Forest runoff (NPS) & 7.9 & 50.0 & 10.0 & - & - & - \\
Sewage and industrial effluent $(\mathbf{P S})^{\#}$ & $\mathbf{2 0 . 0}$ & $\mathbf{1 2 0 . 0}$ & $\mathbf{5 0 . 0}$ & $\mathbf{0 . 2}$ & $\mathbf{1 . 0}$ & $\mathbf{0 . 0 1}$ \\
\hline
\end{tabular}

\# EQA limits in Malaysia for Standard A [8]

In the national urban runoff pollution (NURP) study in the USA revealed that NPS pollution plays significant role in degradation of water quality. However, the composition of the pollutants in the runoff in Malaysia has not been determined and DOE water quality monitoring program does not cover the collection of samples during the rain events when the quality of the river water would be very different from the normal dry periods. Based on the overseas experiences, it can be anticipated that annual pollutant load of certain pollutants (e.g. SS, $\mathrm{Pb}, \mathrm{Zn}, \mathrm{Cu}$, etc.) in the urban centres of Malaysia could be as high as $50 \%$ of the total pollution load entering the rivers. A study on Klang river basin done for the DID indicated that the most common pollutants responsible for water pollution e.g. BOD and $\mathrm{NH}_{3}-\mathrm{N}$ are significantly released from the non-point sources, as shown in Fig. 3. Many of these non-point sources include the sub-urban and squatters areas without proper sanitary system. Another source of sediment-laden pollution in the inland water is sand mining in the rivers. The sand mining activities is a significant source of soil particles and 
makes the water treatment operation very costly by increasing the coagulant (alum) and polymer doses.

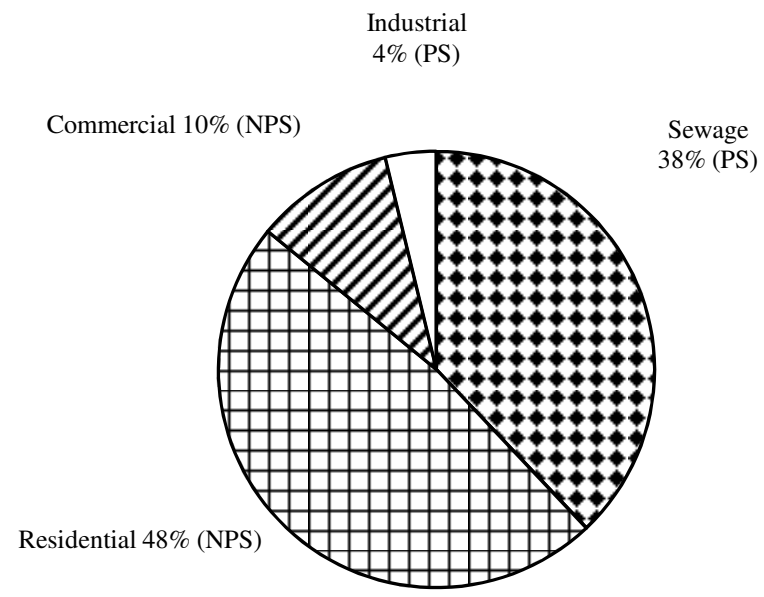

(a) BOD Loading $(\mathrm{kg} / \mathrm{d})$

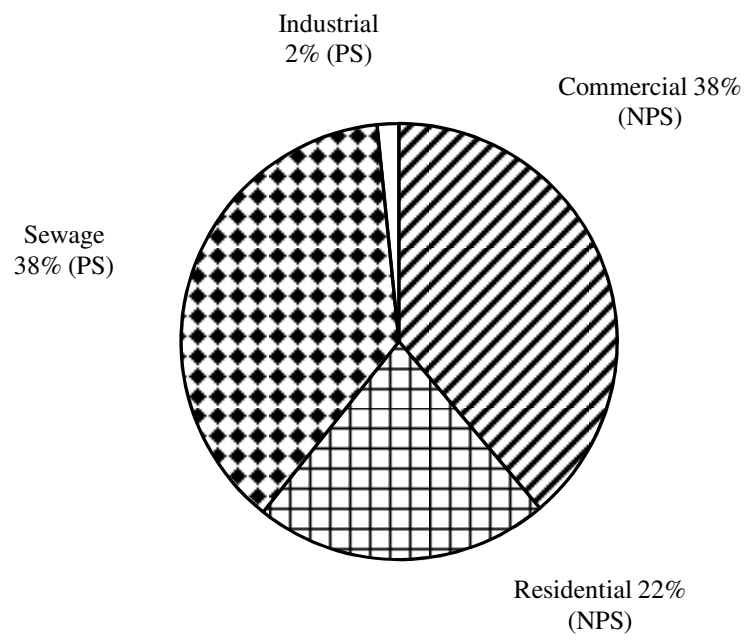

(b) $\mathrm{NH}_{3} \mathrm{~N}$ Loading $(\mathrm{kg} / \mathrm{d})$

Fig. 3: Calculated pollutant load from various sources in Klang river basin [9].

It is reported in the National Water Resources Study 2000-2050 [1] that the parameters which have frequently exceeded Class III limits include ammoniacal nitrogen, organic carbons, heavy metals, oil and grease. Due to pollution problems a few of the rivers namely Sungai. Langat at Bukit Tampoi, Sungai Klang at Shah Alam has been classified into Class IV. According to Table 2, water of Class IV and V are not suitable for the water intakes. It is noted that by improving the quality, more water could be sustainably abstracted from the downstream stretches of the river basins. The pollution problems at the downstream reaches compel the water industry to source water from the upstream areas and also from relatively less polluted river basins. 


\section{EXISTING STANDARDS AND RELATED LEGISLATIONS}

The most frequently referred locals guidelines related to the water quality are the EQA, NWQS and the Malaysian Water Association's (MWA) raw water quality criteria for the intakes. The standards of related parameters are given in Table 2 and Table 3 for references. Description of the classes, in terms of the utility, is also given in this section.

Malaysia suffers from existence of many sectoral-based water laws, both at Federal and state levels but lacks a comprehensive water law, which should safeguard both quantity and quality of water and wastewater. The water legislations are contained within the laws, which are enforced by the various water related government agencies and many are outdated, redundant or ambiguous [6]. These diversified water legislations are focused on limited aspects of water resources and difficult to enforce effectively. There is a need to enact a comprehensive water law that can deal the water quantity and quality issues effectively.

Effective regulation of wet-weather pollution management relies on the establishment of a comprehensive legislative framework. Current situation calls for revising and repealing outdated laws and introducing additional regulations and procedures in line with usual practices. The Water Act 1920 provides that "the entire property and control of all rivers in any State is and shall be vested solely in the Ruler of such State". If required, Federal Government shall play its role only for the water bodies shared or bordered by several states. The other legislations to control water pollution are the Mining Act 1929, the Forest Enactment 1935, the Drainage Works Ordinance 1954 and the Land Conservation Act 1960. The latest is the Environmental Quality Act 1974 (revised in 1979 and 2009), which provide the regulatory control of point pollution sources. The other guideline mainly focused to reduce flood and NPS pollutant is MSMA [3]

Table 2: Excerpt of National Water Quality Standards (NWQS) for Malaysia.

\begin{tabular}{lcccccc}
\hline \multirow{2}{*}{ Parameter } & Unit & \multicolumn{5}{c}{ Limits for Classes } \\
\cline { 3 - 7 } & & I & II & III & IV & V \\
\hline \multirow{2}{*}{ Ammoniacal Nitrogen } & $(\mathrm{mg} / \mathrm{l})$ & $<0.1$ & $0.1-0.3$ & $0.3-0.9$ & $0.9-2.7$ & $>2.7$ \\
BOD & $(\mathrm{mg} / \mathrm{l})$ & $<1$ & $1-3$ & $3-6$ & $6-12$ & $>12$ \\
COD & $(\mathrm{mg} / \mathrm{l})$ & $<10$ & $10-25$ & $25-50$ & $50-100$ & $>100$ \\
Dissolved Oxygen & $(\mathrm{mg} / \mathrm{l})$ & $>7$ & $5-7$ & $3-5$ & $1-3$ & $<1$ \\
pH & - & $>7.0$ & $6.0-7.0$ & $5.0-6.0$ & $<5.0$ & $<5.0$ \\
Total Suspended Solids & $(\mathrm{mg} / \mathrm{l})$ & $<2.5$ & $25-50$ & $50-150$ & $50-30$ & $>300$ \\
\hline
\end{tabular}

CLASS I: Represent water bodies of excellent quality. Standards are set for the conservation of natural environment in its undisturbed state.

CLASS IIA: Represent water bodies of good quality. Most existing raw water supply sources come under this category. Class IIA standards are set for the protection of human health and sensitive aquatic species.

CLASS IIB: The determination of Class IIB standard is based on criteria for recreational use and protection of sensitive aquatic species.

CLASS III: Is defined with the primary objective of protecting common and moderately tolerant aquatic species of economic value. Water under this classification may be used for water supply with extensive/advanced treatment.

CLASS IV: Defines water quality required for major agricultural irrigation activities which may not cover minor applications to sensitive crops.

CLASS V: Represents other water, which do not meet any of the above uses. 
Table 3: Wastewater Discharge Standards and Raw Water Quality Criteria for Malaysia.

\begin{tabular}{|c|c|c|c|}
\hline \multirow{2}{*}{$\begin{array}{c}\text { Parameter } \\
\text { (mg/l unless otherwise stated) }\end{array}$} & \multicolumn{2}{|c|}{$\begin{array}{l}\text { Maximum Permitted Values } \\
\text { ( DOE, 2009; DOE, 1974) }\end{array}$} & \multirow{2}{*}{$\begin{array}{l}\text { Raw Water } \\
\text { Quality [10] }\end{array}$} \\
\hline & Standard A & Standard B & \\
\hline Temperature $\left({ }^{\circ} \mathbf{C}\right)$ & 40 & 40 & - \\
\hline pH (units) & $6.0-9.0$ & $5.5-9.0$ & $5.5-9.0$ \\
\hline BOD $_{5}$ at $20^{\circ} \mathrm{C}$ & 20 & 50 & 6 \\
\hline COD & $120(50)$ & $200(100)$ & 10 \\
\hline Suspended Solids & 50 & 100 & - \\
\hline Mercury & 0.005 & 0.05 & 0.001 \\
\hline Cadmium & 0.01 & 0.02 & 0.005 \\
\hline Chromium, hexavalent & 0.05 & 0.05 & 0.05 (Total) \\
\hline Arsenic & 0.05 & 0.10 & 0.05 \\
\hline Cyanide & 0.05 & 0.10 & 0.1 \\
\hline Lead & 0.10 & 0.50 & 0.1 \\
\hline Chromium, trivalent & 0.20 & 1.0 & - \\
\hline Copper & 0.20 & 1.0 & 1.0 \\
\hline Manganese & 0.20 & 1.0 & 0.2 \\
\hline Nickel & 0.20 & 1.0 & - \\
\hline Tin & 0.20 & 1.0 & - \\
\hline Zinc & $2.0(1.0)$ & $2.0(1.0)$ & 1.5 \\
\hline Boron & 1.0 & 4.0 & - \\
\hline Iron & 1.0 & 5.0 & - \\
\hline Silver & $0.1(-)$ & $1.0(-)$ & - \\
\hline Aluminium & $10(-)$ & $15(-)$ & - \\
\hline Selenium & $0.02(-)$ & $0.5(-)$ & - \\
\hline Barium & $1.0(-)$ & $2.0(-)$ & - \\
\hline Fluoride & $2.0(-)$ & $5.0(-)$ & - \\
\hline Formaldehyde & $1.0(-)$ & $2.0(-)$ & - \\
\hline Phenol & 0.001 & 1.0 & 0.002 \\
\hline Free Chlorine & 1 & 2.0 & - \\
\hline Sulphide & 0.50 & 0.50 & - \\
\hline Ammoniacal Nitrogen & $10.0(-)$ & $20.0(-)$ & - \\
\hline Colour (ADMI*) & $100(-)$ & $200(-)$ & - \\
\hline
\end{tabular}

\section{PROCEDURE TO DETERMINE WATER QUALITY INDEX}

Six parameters namely dissolved oxygen (DO), biochemical oxygen demand (BOD), chemical oxygen demand (COD), suspended solids (SS), ammoniacal nitrogen $\left(\mathrm{NH}_{3}-\mathrm{N}\right)$ and $\mathrm{pH}$ are considered for the evaluation of overall status of the river water. The water quality index (WQI) approved by the DOE (Eqn. 1) is calculated based on the above six parameters. Among those, DO carries maximum weightage of $22 \%$ and $\mathrm{pH}$ carries the minimum of $12 \%$ in the WQI equation. The WQI equation eventually consists of the subindices, which are calculated according to the best-fit relations given in Eqns. 2 to 7. Variations of the sub-indices with concentrations of the respective pollutants are shown in Fig. 4. High value of the index indicates better quality of water. 


$$
W Q I=0.22 S I_{D O}+0.19 S I_{B O D}+0.16 S I_{C O D}+0.15 S I_{A N}+0.16 S I_{S S}+0.12 S I_{p H}
$$

Where, WQI = Water quality index; $\mathrm{SI}_{\mathrm{DO}}=\mathrm{Sub}$-index of $\mathrm{DO} ; \mathrm{SI}_{\mathrm{BOD}}=\mathrm{Sub}$-index of BOD; $\mathrm{SI}_{\mathrm{COD}}=$ Sub-index of COD; $\mathrm{SI}_{\mathrm{AN}}=$ Sub-index of $\mathrm{NH}_{3}-\mathrm{N}$; $\mathrm{SI}_{\mathrm{SS}}=$ Sub-index of TSS; $\mathrm{SI}_{\mathrm{pH}}=\mathrm{Sub}$-index of $\mathrm{pH}$. All pollutant concentrations are in $m g / l$ except for $\mathrm{pH}$.

Sub-index for DO (in \% saturation):

$$
S I_{D O}= \begin{cases}0 & \text { for } D O<8 \\ 100 & \text { for } D O>92 \\ -0.395+0.030 D O 2-0.00020 D O 3 & \text { for } 8<D O<92\end{cases}
$$

Sub-index for BOD:

$$
S I_{B O D}= \begin{cases}100.4-4.23 B O D & \text { for } B O D<5 \\ 108 e^{-0.055 B O D}-0.1 B O D & \text { for } B O D>5\end{cases}
$$

Sub-index for COD:

$$
S I_{C O D}= \begin{cases}-1.33 C O D+99.1 & \text { for } C O D<20 \\ =103 e^{-0.0157 C O D}-0.04 C O D & \text { for } C O D>20\end{cases}
$$

Sub-index for AN (AN is abbreviation of ammonical nitrogen, NH3-N):

$$
S I_{A N}= \begin{cases}100.5-105 A N & \text { for } A N<0.3 \\ 94 e^{-0.573 A N}-5|A N-2| & \text { for } 0.3<A N<4 \\ 0 & \text { for } A N>4\end{cases}
$$

Sub-index for SS:

$$
S I_{S S}= \begin{cases}97.5 e^{-0.00676 S S}+0.05 S S & \text { for } S S<100 \\ 71 e^{-0.0016 S S}-0.015 S S & \text { for } 100<S S<1000 \\ 0 & \text { for } S S>1000\end{cases}
$$

Sub-index for $\mathrm{pH}$ :

$$
S I_{p H}= \begin{cases}17.2-17.2 p H+5.02 p H^{2} & \text { for } p H<5.5 \\ -242+95.5 p H-6.67 p H^{2} & \text { for } 5.5<p H<7 \\ -181+82.4 p H-6.05 p H^{2} & \text { for } 7<p H<8.75 \\ 536-77.0 p H+2.76 p H^{2} & \text { for } p H>8.75\end{cases}
$$



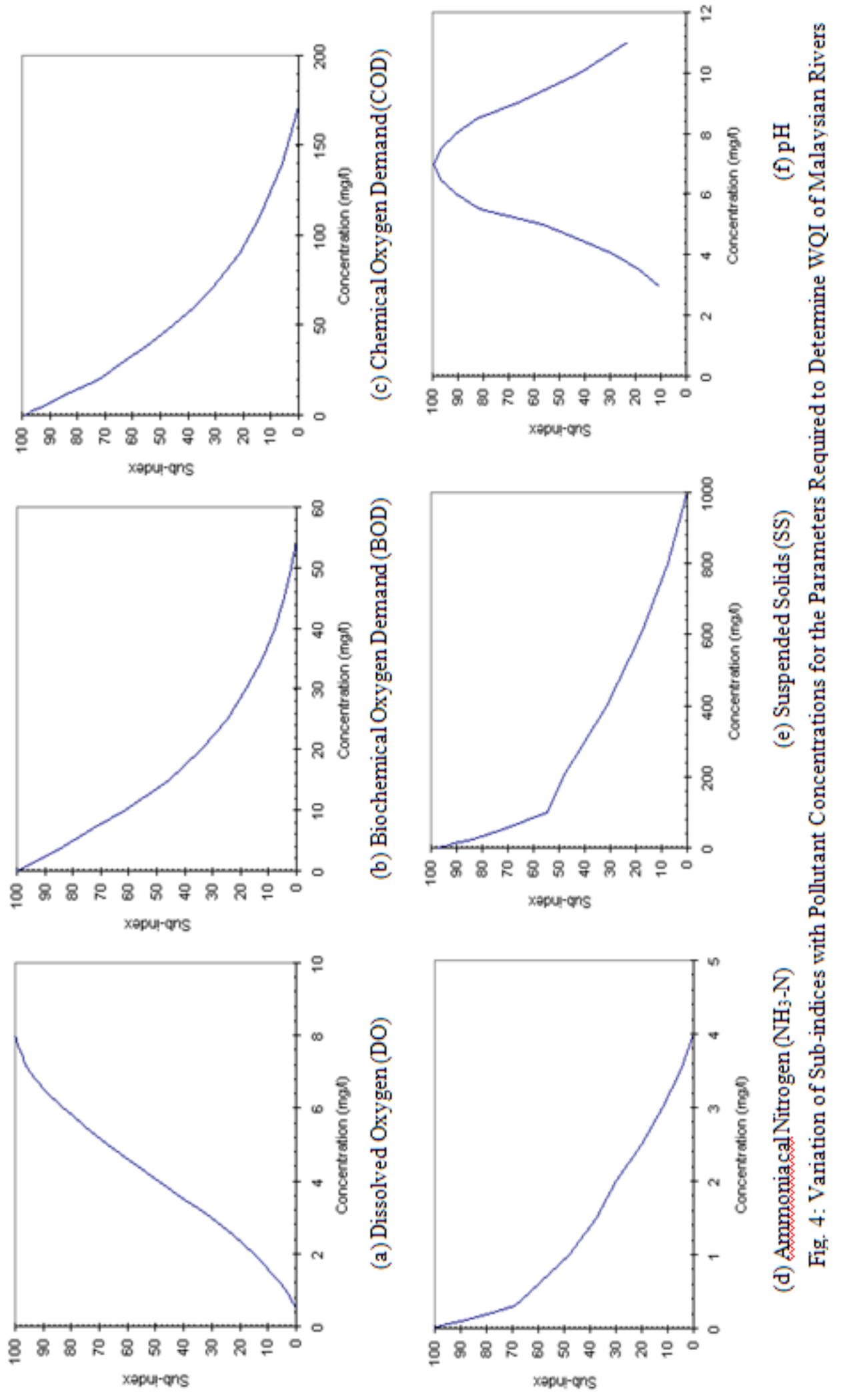
According to the equation, sub-index of DO increases with the increase in concentration while for others it decreases at different rates. In the case of $\mathrm{pH}$, the index follows decreasing trend as it is deviated from the neutral value of 7 (Fig. 4f). The equations (2 to 7) indicate smooth variations of indices for $\mathrm{DO}, \mathrm{BOD}_{5}, \mathrm{COD}$ and $\mathrm{pH}$ when their concentrations are changed. In the case of $\mathrm{NH}_{3}-\mathrm{N}$ and $\mathrm{SS}$, the values decrease sharply until 0.3 and $100 \mathrm{mg} / \mathrm{l}$, respectively (Fig. $4 \mathrm{~d}$ and $4 \mathrm{e}$ ). According to the equations, maximum values of sub-index for COD, SS and $\mathrm{pH}$ could be achieved up to 99.1, 97.5 and 99.4 but not 100 as possible for others. The concentrations of $\mathrm{DO}, \mathrm{BOD}_{5}, \mathrm{COD}, \mathrm{NH}_{3}-\mathrm{N}$ and SS that results in zero (0) value of sub-index are 0.5, 54.3, 172.0, 4.0 and 1000, respectively. It was observed that except $\mathrm{NH}_{3}-\mathrm{N}$, all these values exceed the limits stated in the effluent standard A and B of the EQA. It is realised that the lower and upper limits of the parameters should be revised with respect to the effluent standards and the requirements for raw water quality criteria set by the MWA. The revision is necessary, especially for the rehabilitation of urban rivers, which does not have much baseflow due to high impervious in the river basin.

\section{REVIEW OF THE WQI METHOD}

It was observed that both the national water quality standard (NWQS) and the raw water quality criteria set by MWA contain many parameters, compared to six in the WQI equations. It is not practical to consider all parameters for evaluation purposes. Polluted or clean water is a relative term and expressions to describe the status of water quality mainly depend on the beneficial water use. Based on the long-term observation of the DOE data, it was realised that $\mathrm{pH}$ is not a problem and the weightage of $\mathrm{pH}$ in the WQI equation can be reviewed or even taken out of the WQI equation. A comprehensive analysis is required to identify the main and most frequently detected pollutants in the water and revise the WQI equations. It should consist of the most frequently detected and polluting elements, including heavy metals, herbicides, pesticides, coliform, etc. The upper and lower limits of the WQI determining parameters need to be reviewed and set appropriately considering the requirement of the effluent standards, raw water quality criteria and other specific requirements. The WQI may cover more parameters, including the carcinogenic and toxic elements as mentioned above, for wide range applicability of the indices. The DOE has taken initiative to rehabilitate 26 polluted rivers to Class II standard [5]. In order to improve the quality from the highest level of Class III to the lowest level of Class II, the minimum improvement required, in terms of numerical WQI value, is 24.6 units (i.e. from 51.9 to 76.5 , as given in Table 2). The numerical points among the Classes are also not uniform. With the increased awareness among the people and decreased assimilative capacities of the rivers due to reduced baseflow caused by urbanisation, it is necessary to review the limits of the WQI values including individual parameters of the NWQS.

One major issue should be considered is that the limits of $\mathrm{NH}_{3}-\mathrm{N}$ was not set in the EQA, 1974 but is considered in the revised regulation in 2009 with high concentration (10 and $20 \mathrm{mg} / \mathrm{l}$ for Standard A and B, respectively). It was noticed by the practitioners that $\mathrm{NH}_{3}-\mathrm{N}$ is one of the main pollutants that render WQI value low. Although the influence of $\mathrm{NH}_{3}-\mathrm{N}$ sub-index on the overall equation is $15 \%$ only, the sub-index decreases rapidly with the increased concentration of $\mathrm{NH}_{3}-\mathrm{N}$ (Fig. 4d). Another inconsistency is that, there is Class IIA and IIB in the NWQS but the WQI does not have such categories (Table 2). As such, the Class II in the WQI method may be split into two sub-classes as mentioned in the NWQS. Even the Chemical Oxygen Demand (COD) in the new DOE regulation [8] for standard A sewage is increased from $50 \mathrm{mg} / \mathrm{l}$ to $120 \mathrm{mg} / \mathrm{l}$, which might aggravate the water quality in the rivers. 


\section{CASE STUDY}

In the Eighth Malaysia Plan (2001-2005) the DOE took initiative to control pollution and rehabilitate 26 polluted rivers up to the standard of Class II. This embarkation admits that quality is important for sustainable uses of river water. This section describes case studies of three river basins under the DOE scheme of river rehabilitation. One is Sungai Langat in Selangor and the others are Sungai Tebrau and Sungai Segget in Johor. Existing status of the rivers are discussed below and different scenarios were analysed with a target to achieve Class II standards.

Existing status of the rivers at different stations, including the concentrations of the selected parameters and WQI values, are given in Table 4. In general, Sg. Langat is affected by high COD, SS and $\mathrm{NH}_{3}-\mathrm{N}$ [12] but Sungai Tebrau and Segget suffers from $\mathrm{COD}$ and $\mathrm{NH}_{3}-\mathrm{N}$ problems [13]. Most of the stations in these river basins recorded water inferior to Class III, which indicated that the water are generally not suitable for raw water intakes, especially at the places where the rivers passes through the developed areas, either residential, commercial or industrial. Besides the DOE data, additional water quality data were collected by individual study $[12,13,14]$ to identify the contributing sources of the pollutants, which include both point and non-point sources. In order to achieve Class II in the rivers, the point sources would be identified and the problematic or ineffective sewage treatment plants (STPs) would be asked to upgrade.

The non-point source pollutants mainly from the storm runoff will be diverted to the water quality treatment trains as proposed in the Manual Saliran Mesra Alam - MSMA [3], which includes swale, infiltration facility, bioretention, gross pollutant traps (GPTs), sediment ponds, wet ponds, wetlands, etc. Possible ways to improve water quality (as WQI) in the rivers are increasing dissolve oxygen (DO) by aeration, decreasing BOD, $\mathrm{COD}, \mathrm{NH}_{3}-\mathrm{N}$ by appropriate treatment and reducing $\mathrm{SS}$ from point and non-point sources.

A few options are planned, as given in Table 5, to achieve Class II from the existing status of the rivers (especially during dry period). In order to achieve that target, concentration of few pollutants at some locations (stations) need to be reduced by various percentages are given in Table 6 . The options are set based on the achievable target of pollutant concentration. These case studies show that despite the EQA, status of the rivers is not healthy and significant efforts are necessary to upgrade the rivers up to the level of Class II.

Table 5: A few feasible options to achieve Class II river in the polluted basins.

\begin{tabular}{ccccccc}
\hline \multirow{2}{*}{ Options } & \multicolumn{6}{c}{ Pollutant Concentration (mg/l) to Achieve Class II Water in the Rivers } \\
\cline { 2 - 7 } & DO & BOD & COD & $\mathbf{N H}_{3}-\mathbf{N}$ & TSS & $\mathbf{p H}$ \\
\hline $\mathbf{1}$ & 6.0 & 4.0 & 20.0 & 1.5 & 20.0 & 6.5 \\
$\mathbf{2}$ & 6.0 & 3.0 & 30.0 & 1.0 & 30.0 & 6.5 \\
$\mathbf{3}$ & 6.0 & 5.0 & 15.0 & 1.0 & 45.0 & 6.5 \\
$\mathbf{4}$ & 6.5 & 5.0 & 15.0 & 1.3 & 50.0 & 6.5 \\
\hline
\end{tabular}

\section{UPGRADING THE REQUIREMENTS}

The nation is heading towards urbanization and industrialization. People are migrating more to the urban areas in search of job and to lead a better life. Our rivers, especially at the urban stretches, are being stressed due to reduced base flow (dry weather 
hour) resulting in decreased assimilative capacity and increased pollution loading. During the normal days, most of the urban rivers carry light brown, brown and dark colour of water, which are mainly from the point sources. Water quality in the rivers during the storms is yet to be monitored for long term. Thus, it was realized that comprehensive studies are required to check back the water quality standards set for various purposes (sewage, industrial effluent, WQI, NWQS, raw water quality, etc.).

\section{CONSIDERATION OF OTHER INDICES}

Good quality of water is more essential for the aquatic flora and fauna. Water quality criteria should be more stringent for their survival and ecological balance. For holistic and sustainable use of water other appropriate indices e.g. Harkin's objective index, ShanninWiener diversity index (H), SCI diversity index, index of biotic integrity (IBI), index of saprobic condition (S), etc. could be considered [11]. This is important because, the normal monitoring program cannot evaluate the river's ecological status. At least biannual or quarterly sampling of planktons, macrophytes, invertebrates, fish and other aquatic flora and fauna should be done to determine the biological integrity of the rivers in various seasons.

\section{CONCLUDING REMARKS}

Malaysia receives adequate rainwater to meet the increasing water demand of the nation. However, despite the EQA, water quality of many rivers is deteriorating in the country. A few of the water treatment plants (WTPs) are reported to have problems with raw water quality and had been temporarily shut down several times. The mismatch between availability and demand for water is aggravated by pollution of water sources. Water shortage is aggravated by the pollution due to point and non-point sources pollution.

During the low flows, the water quality is adversely affected due to inadequate dilution and makes the water unacceptable or costly to treat. The existing legislations, guidelines, standard and procedures to evaluate water quality are discussed. It is recommended to review the WQI equations and procedure, effluent discharge standards in the EQA and limiting values of the NWQS to reduce the inconsistencies and to increase compatibility. The EQA allows discharge of various concentrations of pollutants depending on the source of wastewater. However, the ecosystem does not care whether the pollution load is from sewage, industrial effluent, sullage or storm runoff. Therefore, a unified wastewater discharge standard (irrespective of the source) would safeguard the water bodies and aquatic lives in a sustainable manner.

Case studies in three river basins indicated that most of the urban rivers are stressed and not suitable for water intakes, making the water supply more costly. To make the water resources sustainable for all living beings, other appropriate indices should be adopted and evaluated at reasonable intervals. Realising the importance of the quality of water, it is recommended to undertake strict measures on water quality control, monitoring criteria and standards, including control of point and non-point pollutions. 


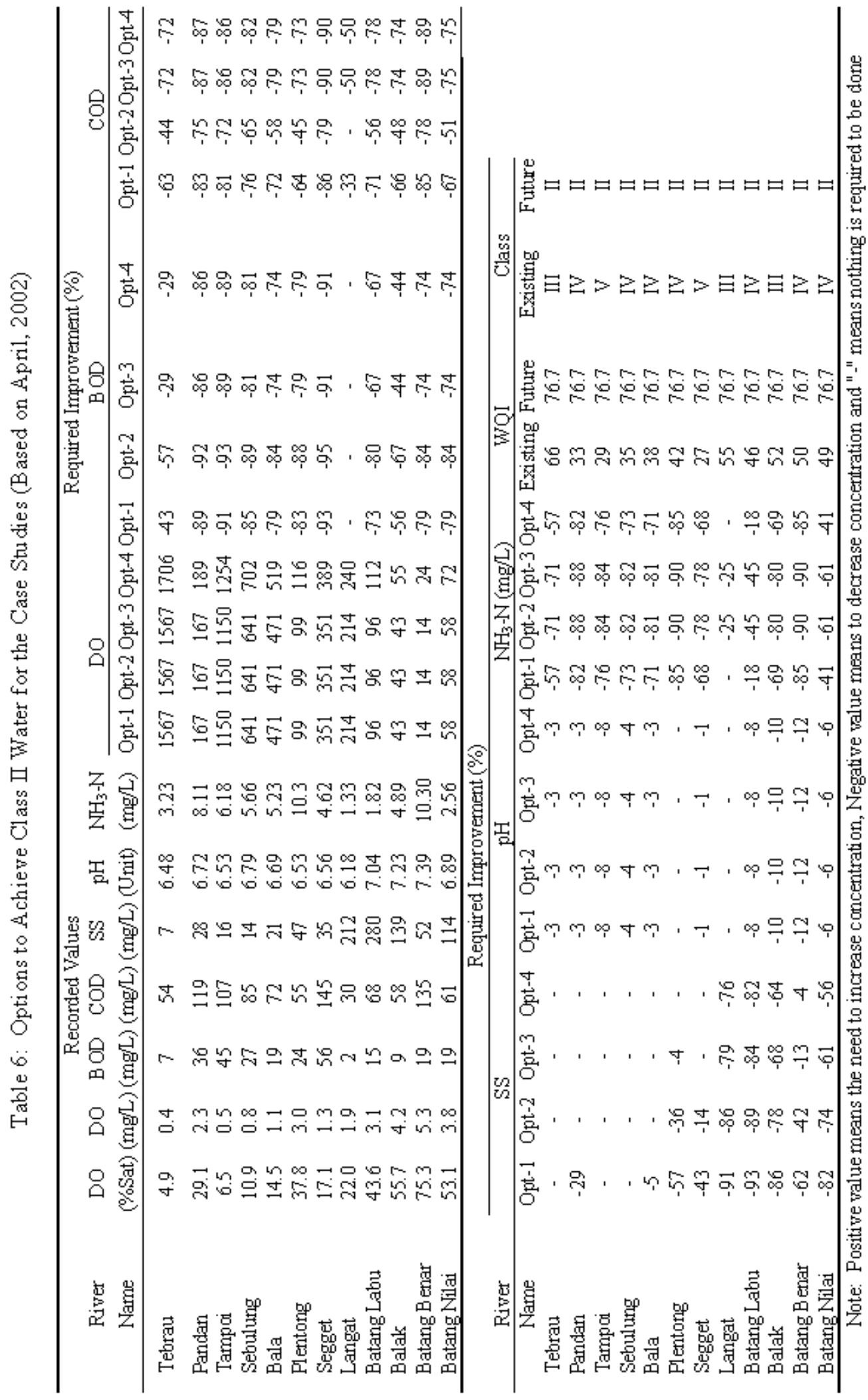




\section{ACKNOWLEDGEMENT}

The authors gratefully acknowledge the data provided by the DOE, ASMA, DID and other sources.

\section{REFERENCES}

[1] Economic Planning Unit - EPU. "National Water Resources Study 2000 - 2050". Government of Malaysia, Department of Prime Minister's Office 2000.

[2] Department of Environment Malaysia - DOE. "Environmental Quality Act 1974 (Act 127) \& Subsidiary Legislations". Government of Malaysia, Ministry of Science, Environment and Technology. International Law Book Services, 1974.

[3] Department of Irrigation and Drainage - DID. "Urban Stormwater Management Manual for Malaysia". Government of Malaysia, Ministry of Agriculture, Malaysia, 2000.

[4] M.S. Pillay. "Water and Health".. Seminar on World Day for Water. 2001.

[5] D. Hashim. "Water Pollution Control in Malaysia - A Regulator's Perspective". Seminar on World Day for Water. 2001.

[6] A.Keizrul. "The need for Sustainable Water Use and Management". Seminar on World Day for Water. 2001.

[7] United.States. Environmental Protection Agency - USEPA. "Final Report of the Nationwide Urban Runoff Program". Water Planning Division, Washington DC, 1983.

[8] Department of Environment Malaysia - DOE. "Environmental Quality Act 1974 Environmental Quality (Sewage) Regulations 2009". Government of Malaysia, Ministry of Natural Resources and Energy. Percetakan Nasional Malaysia Berhad, October, 2009.

[9] Department of Irrigation and Drainage - DID. "Klang River Basin Environmental Improvement and Flood Mitigation Project". Government of Malaysia, Ministry of Agriculture, Malaysia, 2001.

[10] Malaysian Water Association "Design Guidelines for Water Supply Systems". 1994. Kuala Lumpur: MWA (1994).

[11] Department of Environment Malaysia - DOE. "Classification of Malaysian Rivers". Final report on development of water quality criteria and standards for Malaysia (Phase IV River Classification). Government of Malaysia, Ministry of science, technology and the environment, 1994.

[12] Department of Environment Malaysia - DOE. "The study of pollution prevention and water quality improvement of Sungai Langat". Government of Malaysia, Ministry of science, technology and the environment, $2003 \mathrm{a}$.

[13] Department of Environment Malaysia - DOE. "The study of pollution prevention and water quality improvement of Sungai Tebrau and Sungai Segget". Government of Malaysia, Ministry of science, technology and the environment, 2003b.

[14] Department of Environment Malaysia - DOE. The study on pollution prevention and water quality improvement of Sg. Melaka. Government of Malaysia, Ministry of natural resources and environment Malaysia, 2004 